\title{
Opetuksen ja tutkimuksen tuloksellisuus
}

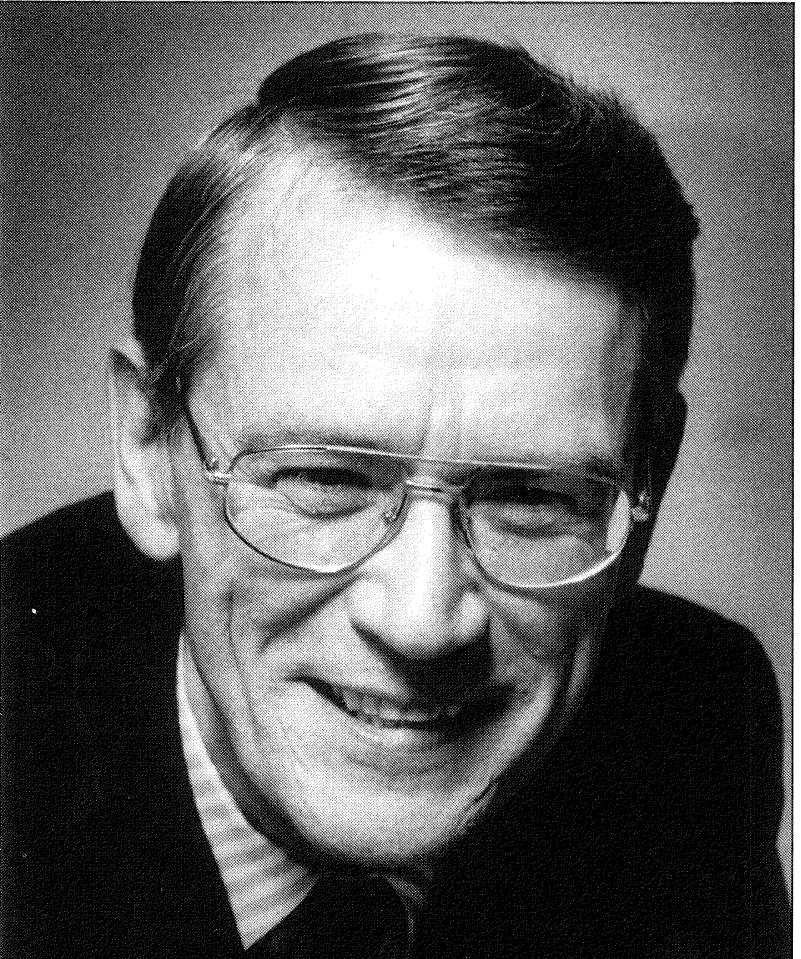

Alussa loi Jumala taivaan ja maan...

Ja Jumala katsoi kaikkea,

mitä bän tebnyt oli

ja katso, se oli sangen byvää.

Ja tuli ebtoo, ja tuli aamu,

kuudes päivä...

Ja Jumala lepäsi seitsemäntenä päivänä kaikesta työstänsä, jonka bän oli tebnyt. Hänen arkkienkelinsä tuli silloin Hänen luokseen ja kysyi:

"Jumala, mistä tiedät, että kaikki, minkä Sinä loit, on 'sangen byvää?? Mitkä ovat Sinun kriteerisi?

Mille aineistolle perustat arviosi?

Etkö ole liiaksi asianosainen tehdäksesi reilun ja puolueettoman arvion?" Jumala mietti näitä kysymyksiä koko sen päivän,

ja Hänen leponsa bäiriintyi suuresti.

Kabdeksantena päivänä Jumala sanoi:

"Lucifer, painu belvettiin!"

Näin syntyi evaluaatio kunnian

loisteessa.

Ja aina siitä asti on evaluojien

ammattikunnan status ollut

jonkinverran epäilyksenalainen:

joko tie pelastukseen tai

varma lippu kadotukseen.

(Halcolm: The Real Story of Paradise Lost)

Toinen lainaukseni tulee Koululaisen muistikirjasta runsaan 40 vuoden takaa. Kumpi painaa enemmän, kilo rautaa vai kilo höyheniä? Yliopistoväki on suhtautunut tulosbudjetointiin ja tulosjohtamiseen mittaamisineen yhtä hämmentyneinä kuin koululaiset kompakysymykseensä. Samalla mittayksiköllä ja samalla vaa'allako tulisi mitata rautaa ja höyheniä tai luonnontieteitä ja humanistisia tieteitä, opetusta ja tutkimusta? Uusi hallinto- ja kontrolli-ideologia on sekoittunut laatuajatteluun erottamattomaksi vyyhdeksi, jossa syyt ja seuraukset, keinot ja päämäärät sekoitetaan ja analysoimatta kirjataan Reijo Raivola ja puristetaan laatua ja toiminta-aktiivisuutta osoittaviksi indikaattoreiksi. 
Opetukselta ja tutkimukselta vaaditaan tuloksellisuutta kykenemättä tarkoin määrittelemään, mitä se on, ja ymmärtämättä, miten panokset tuottavat määrätynlaisia prosesseja ja nämä puolestaan vaihtelevia tuotoksia. Samoja evaluaatioprosesseja ja indikaattoreita halutaan käyttää yhtä hyvin itseohjautuvuuden kehittämiseen kuin voimavarojen epätasaisen jaon perustelemiseen. Varsinkin opetushallinnossa vallitsee jopa mittaamisen ja tilastoinnin hysteria ilman, että toimintaa ohjaisi selvä evaluaatiologiikka tai evaluaatiotieteen paradigma. Eri evaluaationäkemyksistä poimitaan valikoivasti tulosohjauksen ideologiaa tukevat piirteet huomaamatta, että tuloksena saattaa olla sisäisesti ristiriitainen ja toteuttamiskelvoton kehys.

Positivismin epäillyttävin lahja yhteiskuntatieteille on ollut käsitteiden operatiivinen määrittely, mikä edelleenkin näkyy siinä tulosvastuuta korostavassa suuntauksessa, joka määrittelee moninaiset tavoitteet ja suoritukset yksittäisinä määrällisinä indikaattoreina. Moni yliopistolainen mielellään miettii J.A. Holloa mukaillen, että arviointiasiassa yhtä köyttä vetävät vain ne, joiden pitäisi siinä riippua.

$\mathbf{P}$ rofessionaaliset tutkijat ja opettajat pitävät hallintobyrokraattien ja poliitikkojen asiantuntematonta määräilyä sietämättömänä puuttumisena asioihin, joita he eivät ymmärrä. Kansan valitsemat johtajat ja itse itselleen mandaatin antaneet virkamiehet puolestaan korostavat korkeakoulutuksen ja tutkimuksen asemaa julkisena instituutiona, jonka on alistuttava julkiseen kontrolliin ja taivuttava demokraattisesti valittuun, edustavaan poliittiseen tahtoon tavoitteiden asettelussa ja voimavarojen allokoinnissa.

Korkeakoulut ovat osa julkishallinnon poliittista järjestelmää ja näin poliittisen ohjausjärjestelmän vaikutuspiirissä. Poliittisen järjestelmän ohjauskyky on kuitenkin ratkaisevasti heikentynyt. Julkinen valta kärsii Habermasin osuvasti analysoimasta legitimiteettikriisistä ja sen on ollut kehitettävä kompensoivia legitimointistrategioita. Sellainen on "objektiiviseen" mittaamiseen ja mittalukujen indikaatoreiksi yhdistämiseen perustuva voimavarojen jako- ja palkitsemisjärjestelmä. Tavoitejohtaminen on muuttunut tulosjohtamiseksi. Uusi, ainoa oikea ja lopullinen poliittinen ja manageriaalinen ideologia on löytynyt.
Ei muisteta Mark Twainin toteamusta, että tämän päivän alttarivaate on huomisen kynnysmatto.

Tämän "ismin" argumentointia ja loogista pitävyyttä yliopistolaisten on tiukasti tutkittava ja asetuttava päättävästi vastustamaan, jos aihetta oppositioon löytyy. Lichtenberg, saksalainen 1700-luvun lopulla elänyt fyysikko, käänsi Cartesiuksen kuuluisan toteamuksen 'cogito, ergo sum' ("Ajattelen - siis olen olemassa") negaatioksi 'non cogitant, ergo non sunt' ("Emme ajattele - emme ole olemassa"). Yliopistoihminen, joka kritiikittä omaksuu annetun informaation tietona ja tarjotut toimintatavat, hallinnollinen ohjausideologia mukaan luettuna, ainoina oikeina, ei ajattele itsenäisesti eikä siis ole olemassa tutkijana.

$\mathrm{P}$ ahásti näyttää siltä, että valtaan pyrkivä ohjausideologia luottaa perusteettomasti kaikilla sosiaalisen toiminnan lohkoilla markkinalakeihin, vapaaseen kilpailuun, yksityiseen omistukseen ja voiton maksimointiin.

Ainoan poliittisen ja taloudellisen totuuden julistajat unohtavat, että todellisuus ei vielä ole totuus.

Totuus on koettavissa toimenpiteiden kohteeksi joutuneiden elämismaailmassa. Romain Roland on todennut, että aatteelle saa uhrata vain omansa, ei toisten elämää. Kuitenkin poliittinen ja hallinnollinen johto odottavat meidän tuottavan tunnuslukuja, jotka osoittavat meidän tarpeettomuutemme ja heidän oikeutensa eutanasiaan.

Ei ole ihme, jos itsearviointi tuottaa defensiivisiä raportteja. Poliittisesti käytetty evaluaatio - siitähän on kysymys silloin, kun jaetaan voimavaroja tai pohditaan toiminnan lopettamista - johtaa väistämättä kumuloituvana prosessina toiminnan kannalta negatiiviseen johtopäätökseen. Organisaatiohan on yhteistoiminnallinen ongelmanratkaisun väline. Se antaa turvallisuutta ja vakautta. Ohjelmaevaluaatio implikoi aina muutosta. Organisaatio suhteuttaa aktiviteettinsa toimintaohjelmiin ja asiakkaiden tarpeisiin, evaluaatio julkilausuttuihin tavoitteisiin. Itsearviointikin järkyttää tasapainoa särkemällä vakiintuneen suhteen ohjelman ja asiakkaiden välillä. Pitkälle vietynä evaluaatio kumuloituu itsetuhoksi. 
Sama mekanismi periaatteessa häiritsee uusien ohjelmien synnyttämistä. Tätä logiikkaa Reaganin hallinto taitavasti käytti hyväkseen purkaessaan Carterin hallinnon sosiaaliohjelmia. Poliitikot ja intressiryhmät, joiden kannattajat eivät välittömästi hyödy ohjelmista, kiistävät niiden tavoitteet a priori. Silloin ei tarvitse edes keskustella rahoituksen tasosta tai sisällön relevanssista.

Yritykset puristaa monimutkaiset poliittiset, eettiset ja inhimilliset ongelmat puhtaasti teknisiksi harjoituksiksi saavat yleensä perin konservatiivisen arvolatauksen. Voikin kysyä, ratsastavatko uuskonservatismin suunnannäyttäjät autoritaarisen populismin aallonharjalla? Oikeusnormistossa epäilty on syytön, kunnes toisin näytetään. Tulosvalvonnassa jokainen on "rikollinen", ellei onnistu osoittamaan viattomuuttaan.

\section{Laatuvaatimus - kyllä}

$\mathrm{T}$ yystin toinen asia on pyrkiä myös opetus- ja tutkimustoiminnassa tehokkuuteen ja vaikuttavuuteen eli laatuun. Laadun ulkoisesta valvonnasta on kuitenkin pyrittävä laadun sisäiseen varmistamiseen ja organisaatiossa tapahtuvaan laatujohtamiseen. Jokaisen käsityöläisenkin on ammatin harjoittamisensa alkuvaiheesta lähtien kyettävä tekemään ero hyvän ja huonon tuotteen välillä. Tämän eron näkeminen on ammatissa menestymisen ja kehittymisen välttämätön ehto.

Hyvään tuotteeseen liittyy aina myös kuluttajavalistusta: asiakkaat on opetettava olemaan hyväksymättä huonoa ja puutteellista tuotetta. Nämä periaatteet eivät voi olla vieraita henkiselle toiminnallekaan.

Jokaisella tavoitteisella organisaatiolla on oltava selvä käsitys tehtävästään ja tarjoamistaan palveluista.

Nykyiset organisaatioteoriat ja laatujärjestelmät pitävät asiakaskeskeisyyttä kaiken toiminnan lähtökohtana. Korkeakoulujenkin on tunnistettava asiakkaansa, koulutus- ja tutkimuspalvelujen käyttäjät, ja otettava heidän tarpeensa riittävässä määrin huomioon. Opiskelijoita en kuitenkaan pidä asiakkaina, koska juuri tämä määrittely on ollut tekemässä korkeakouluja su- permarketeiksi tai voileipäpöydiksi. Opiskelijat on nähtävä nuorempina kolleegoina, joiden kasvutarpeet on kyettävä yhdistämään asiakaskunnan palveluodotuksiin.

Kiistanalaista on myös, onko organisaation aina tuotettava sellaisia palveluita kuin asiakkaat haluavat. Erääksi professionaalisen ammatinharjoittamisen piirteeksi on esitetty, että ammattimies voi ja uskaltaa toimia asiakkaan ja maksajan tahdon vastaisesti silloin, kun hän katsoo sen asiakkaan tarpeiden tyydyttämisen ja hyvinvoinnin kannalta välttämättömäksi.

Toimijoiden on osattava tuottaa palvelut tehokkaasti ja vaikuttavasti. Johdolla on oltava keinot ohjata järjestelmää sekä ylläpitää ja kehittää toimintaa. Johto- ja laatujärjestelmät itsessään ovat myös jatkuvan arvioinnin kohteena (metaevaluaatio). Jokainen organisaatio tarvitsee johdon välineeksi tehokkaan informaatio- ja viestintäjärjestelmän, koska laatujohtaminen ja laadun varmistus on integroitu tieto- ja taitopainotteiseksi järjestelmäksi. Se ei ole normiohjauksinen.

\section{Evaluaatiotoiminta - kyllä}

$\int$ okaisen pysyväksi tarkoitetun toiminnan on kyettävä osoittamaan, miten ansiokasta ja laadukasta toiminta on ja onko edistystä tapahtunut (merit). Arviointiin on myös sisällytettävä evaluaatiojohtopäätös: miten mielekästä ja tarpeellista toimintaa on jatkaa. Kysymyksessä on arvon (worth) määrittäminen. Tähän tehtävään ei riitä pelkästään evaluoivan näkökulman omaksuminen omaan toimintaan. Tarvitaan evaluaatiotieteen apua, niin vastenmielistä kuin objektiivisuusharhan valtaaman tutkijan onkin tehdä arvopäätelmiä ja tunnustaa niitä tuottava toiminta tieteeksi.

Yksi positivismin harhoista on ollut julistautuminen arvoista riippumattomaksi, absoluuttisen objektiiviseksi. Tämä arvofobia on tunkeutunut kaikkialle. Tutkijat ja opettajat, jotka jatkuvasti arvioivat ja arvostelevat opiskelijoita ja kollegoitaan, kieltäytyvät itse alistamasta toimintansa perusteita arvioinnin kohteeksi. Ohjelman ja organisaation arviointi on kuitenkin perimmiltään niissä toimivien henkilöiden toiminnan arviointia. 
$\mathrm{O}^{\mathrm{p}}$ pettajien arviointi on voimakkaasti tulossa yliopistoihin, ellei muuten niin tulospalkkauksen perusteiden selvittämiseksi.

Tähänastinen keskustelu osoittaa, että arvon ja ansion käsitteitä ei ole ymmärretty pitää toisistaan erillään. Arvon määrittämisessä on kysymys mm. toiminnan ja tuotteiden kysynnästä ja hinnan määrittelystä markkinoilla, laitoksen tai sen opettajan markkina-arvosta ja maineesta sekä suhteesta tiedotusvälineisiin ja mielipiteenmuodostajiin. Ansioiden arvioinnilla ei välttämättä ole mitään tekemistä edellisen kanssa. Siinä on kysymys yksilön ja hänen toimintansa tarkastelemisesta ennalta tietoon saatettuja standardeja vasten. Mielenkiintoiseksi tämä jaottelu käy, kun liitetään siihen siitä seuraavat loogiset johtopäätökset toiminnan jatkamisesta tai lopettamisesta ja henkilöstön asemasta.

Kuvio: Henkilöstöpoliittinen johtopäätös arvon ja ansion määrittämisestä

\begin{tabular}{|l|l|}
\multicolumn{1}{c}{ arvo } \\
\cline { 2 - 2 }+4 \\
ansio \\
$\begin{array}{l}\text { suuntaaminen } \\
\text { lopettaminen }\end{array}$ & $\begin{array}{l}\text { palkitseminen } \\
\text { jatkaminen }\end{array}$ \\
\cline { 2 - 3 } & $\begin{array}{l}\text { erottaminen } \\
\text { lopettaminen } \\
\text { vaihtaminen } \\
\text { jatkaminen }\end{array}$ \\
\hline
\end{tabular}

$\mathrm{Y}$ liopistojen ja niissä tapahtuvan toiminnan ladun määrittäminen on kuitenkin vasta aivan alullaan. Yliopisto ei ole vain tutkintoja ja sitaatteja toisten tutkimuksista tuottava laitos. Se on ennen kaikkea idea ja ideaali, jonka tarpeellisuuden 900-vuotinen historia on osoittanut. Se on myös yksi tekijä monimutkaisessa paikallisessa, kansallisessa ja kansainvälisessä taloudellisten ja sosiaalisten vaikutusten ketjussa, jonka omavaikutuksesta ei ole tarkkaa tietoa. Idean esineellistäminen mitattavaksi tuotteeksi tai kausaaliketjun yhden lenkin irrottaminen uu- delleen taottavaksi ketjua murtamatta on huomattavasti vaikeampi tehtävä kun halki, poikki ja pinoon -mittaajat uskovat.

Vaatimus jokaisen suomalaisen korkeakoulun, jokaisen tiedekunnan, jokaisen laitoksen ja jokaisen tutkija-opettajan maailman tason huippulaadusta hengissä säilymisen ehtona on yhtä järjetön kuin vaatimus, että Suomen tulee olla johtava poliittinen, taloudellinen ja sosiaalinen mahti maailmassa. Uskon jossakin määrin Aaro Hellaakoskea, kun hän väittää, että ainoastaan keskinkertaisuus tekee tasaista jälkeä. Nähtäväksi jää, jos uusi hallinto-oppi elää kyllin kauan, pitääkö myös Oscar Wilden sutkaus paikkansa: "Aina kun pystymme tekemään ihmisiin vaikutuksen, saamme vihamiehiä. Suosiossa pysyäkseen on oltava keskinkertainen."

$\mathrm{O}$ len käyttänyt esityksessäni runsaasti kulttuurihenkilöiden lausumia ajatuksia. Jos sitä tekee liian kanssa, kutsutaan sitä taiteessa plagioinniksi, tuotekehittelyssä teollisuusvakoiluksi ja irtaimen omaisuuden kysymyksessä ollen varastamiseksi. Tieteen instituutiossa sitä kutsutaan siteeraamiseksi. Sillä osoitetaan oma oppineisuus ja aktiivisuus ja se palkitaan akateemisin tai taloudellisin palkkioin, sillä mitä ahkerammin ja monipuolisemmin minä siteeraan muita, sitä todennäköisempää on, että joku siteeraamistani siteeraa myös minua.

Toivon, että esittämääni ei tulkita yliopistolaitoksen puolusteluksi. Sen tarkoitus oli osoittaa, että tuloksellisuuden ja tulosvastuun määrittely ovat erittäin vaikeita ja ennen kaikkea myös moraalisia ja eettisiä kysymyksiä.

Yliopistolaitoksen on kuitenkin aina syytä tutkistella itseään ja olla altis kritiikille. Kenties on niin kuin kriitikot sanovat, että me rakastamme viisautta enemmän kuin se meitä (Lordi Byron). Poliitikkoja ja byrokraatteja voin lohduttaa, että vaikka usein asetumme yliopistossa vastahankaan uusia ismejä kohtaan, ei se merkitse kehityksen pysähtymistä. Ellei ole vastusta, ei ole myöskään kitkaa. Ellei ole kitkaa, ei ole myöskään liikettä.

Julkaistu kirjoitus on Reijo Raivolan virkaanastujaispuhe 8.9.1994 hänen ottaessaan vastaan Tampereen yliopiston kasvatustieteen professuurin. 